\title{
IMMUNOLOGICAL OBSERVATIONS ON EXPERIMENTAL CHOLERA
}

\author{
H. K. GHosH* \\ Department of Bacteriology, University of Edinburgh
}

Although cholera vaccine was the first bacterial prophylactic used in man, its real efficacy remains to be ascertained (see review by Standfast, 1969). Only six of 13 vaccines used in the recent planned field trials, made under the difficult conditions of the endemic areas, showed some protection for short periods.

Intestinal infection of rabbits, which are quite similar pathologically to the human disease, may be expected to provide the most suitable model for experimental study. Here too the results have been contradictory. Metchnikoff (1894), Choukevitch (1911), Sanarelli (1921), and Jenkin and Rowley (1960) had varying successes in passive protection of baby rabbits against infection with Vibrio cholerae with antiserum against formolised or heat-killed vaccines. Jenkin and Rowley also claimed that vaccination protected rabbits against lesions in intestinal loops into which $V$. cholerae had been injected. But Panse, Jhala and Dutta (1964) could protect baby rabbits passively with antiserum to live cultures only; sera produced against formalin- or heat-inactivated vaccine were ineffective. Working with guineapigs infected by mouth, Burrows and Ware (1953) and Freter (1962) concluded that the degree of protection from oral and parenteral vaccines was correlated with the copro-antibody titre against $V$. cholerae, which is generally highest in the 2 nd wk after vaccination and disappears in a further 1 to 2 wk. Accordingly, Freter (1964) has advocated continual oral immunisation.

In all foregoing experiments the same vibrio strain was used for both challenge and vaccination. Only a single arbitrary dosage scheme for immunisation and challenge was used, so that generalisations made about the relative efficacies of the vaccines may be misleading. Only Feeley (1965) stated the potency of his challenge dose, and only Panse et al. compared live and killed vaccines simultaneously. The following experiments were made to compare the efficacy of live and killed cholera vaccines in animals, and also to ascertain the role of copro-antibody by challenging animals both 1 wk and 4 wk after vaccination.

\section{MATERIALS AND METHOD}

Vaccines were prepared by growing freeze-dried vibrio strains on agar. The overnight growth suspended in peptone saline matching 5 IU opacity, i.e., containing $c$. $10^{9}$ bacteria in $1.0 \mathrm{ml}$, made a live vaccine, which was used immediately. Formolised vaccines were made by adding commercial formalin to a live vaccine to a final concentration of 0.1 per cent $\mathrm{v} / \mathrm{v}$ and incubating the mixture for $1 \mathrm{hr}$ at $37^{\circ} \mathrm{C}$. O-antigen vaccines were made by steaming live vaccines for $2 \frac{1}{2} \mathrm{hr}$ and then adding thiomersal, B.P., 1 in $1000(\mathrm{w} / \mathrm{v})$. Killed vaccines were stored up to $1 \mathrm{mth}$ at $2^{\circ}-4^{\circ} \mathrm{C}$.

Received 28 Oct. 1969; accepted 20 Feb. 1970.

* Present address: Jabatan Bakterialogi, Universiti Malaya, Kuala Lumpur.

J. MED. MICROBIOL.--VOL. 3 (1970) 
Vaccination. Guinea-pigs were given doses of 0.1 and later of $0.2 \mathrm{ml}$ of vaccine intraperitoneally once a week for a total of two or four doses. The pre-immunisation serum agglutinin titre was always below 50. A sample of heart blood for antibody titration was collected under ether anaesthesia after immunisation and 2-4 days before challenge. Rabbits were bled from the ear vein. Those with serum agglutinin titres below 50 were vaccinated intravenously with $0.5 \mathrm{ml}$, followed by $1.0 \mathrm{ml}$ once a week for a total of two or four doses. Final serum antibody titres were determined 2-4 days before challenge. Blood used for passive protection tests in baby rabbits was, however, collected $1 \mathrm{wk}$ after the last vaccination. The separated serum was stored at $-20^{\circ} \mathrm{C}$, and $1 \mathrm{ml}$ was injected intraperitoneally into baby

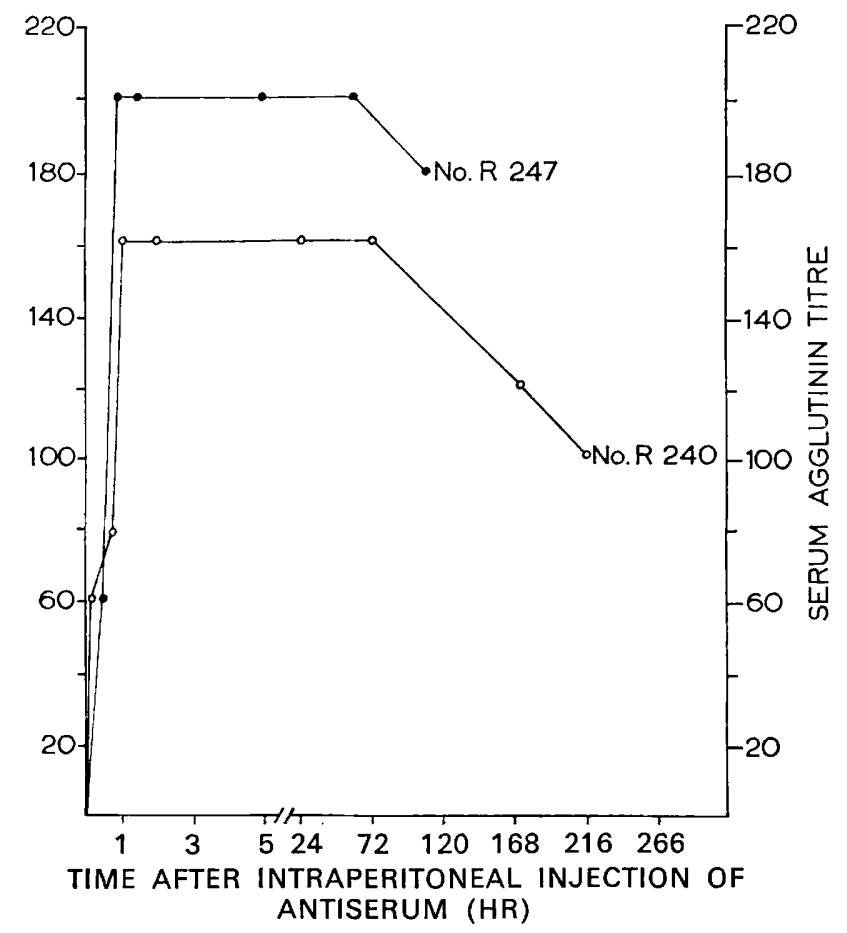

Fig. 1.-Agglutinin titres against Vibrio cholerae in heart blood of two baby rabbits after intraperitoneal administration of $1 \mathrm{ml}$ antiserum from actively immunised rabbits.

rabbits $c .6 \mathrm{hr}$ before challenge. Pilot studies showed that such serum was absorbed within $1 \mathrm{hr}$ (fig. 1). Moreover, when baby rabbits of mixed breeds were infected intra-intestinally with 90-600 colony-forming units (CFU) of $V$. cholerae 12r all of five were protected by giving a homologous antiserum intravenously immediately after challenge, and nine out of ten were protected by giving the antiserum intraperitoneally $6 \mathrm{hr}$ beforehand.

Protection tests. The challenge strain was Vibrio cholerae 12r, Ogawa, whose minimum effective dose (MED) had been shown to be $c .60 \mathrm{CFU}$ for baby rabbits, $10^{5} \mathrm{CFU}$ in rabbit ileal loops and 5 CFU in guinea-pig ileal loops. Graded challenge doses were injected into alternate intestinal loops in rabbits and guinea-pigs. At least one unvaccinated animal was included with each batch of vaccinated rabbits (usually three). The animals were examined at necropsy $c .18 \mathrm{hr}$ later for swelling of the loops.

A control treated with normal serum was also included in each batch of baby rabbits, each of which received an injection of one of three or four antisera prior to challenge. The mean body weight of each treatment group was $c .220 \mathrm{~g}$. The results-death, self-limiting diarrhoea, or no illness-from successive batches were pooled together.

Serum antibody titration. All antibody titres were determined with the challenge strain 
as antigen. When the limiting dilution of serum (before mixture with antigen) that gave definite agglutination by the method of De et al. (1958) was 1 in $x$, the titre was expressed as $x$. The vibriocidal test was made by adding one part of complement, i.e., the pooled serum of 3-4 guinea-pigs, stored at $-20^{\circ} \mathrm{C}$, to 40 volumes of vibrio suspension and then adding the mixture to equal volumes of serial ten-fold serum dilutions. When the highest serum dilution (before mixture with antigen) that reduced the plate count to at least half of that of a saline control was 1 in $y$, the titre was expressed as $y$. In triplicate pilot titrations the end-point had been reproducible within one dilution.

Copro-antibody titration. At necropsy a spot on the caecum wall was seared with a spatula in order to reduce bleeding, and an incision was made through this area. The adherent semi-fluid contents were discarded. About $1 \mathrm{ml}$ of the remaining fluid was collected in a bijou bottle, emulsified in approximately the same volume of saline containing 1 in 1000 thiomersal, kept overnight at $2^{\circ}-4^{\circ} \mathrm{C}$ and then centrifuged at $2000 \mathrm{~g}$ for $15 \mathrm{~min}$. at room temperature $\left(18^{\circ}-22^{\circ} \mathrm{C}\right)$. The supernatant extract was heated for $30 \mathrm{~min}$. at $56^{\circ} \mathrm{C}$, mainly to destroy enzymes. The agglutinin titre was determined from a starting dilution of 1 in 5 . The vibriocidal test proved unsatisfactory, presumably because of a high anticomplementary action of intestinal contents.

Passage of intraperitoneally injected antibody into ileum in baby rabbits. 3-5 $\mathrm{ml}$ antiserum were concentrated to $c .1 \mathrm{ml}$ by dialysis against polyethylene glycol and then against saline at $2^{\circ}-4^{\circ} \mathrm{C}$ for $24 \mathrm{hr}$. The concentrate was injected intraperitoneally into a baby rabbit. After the desired interval heart blood was collected for antibody titration. The abdomen was opened, and a length of $c .15 \mathrm{~cm}$ of the ileum was tied off at both ends. The segment was removed by severing the mesentery close to the gut. It was washed briefly in ice-cold saline, which also caused contraction of the blood vessels. Then $1 \mathrm{ml}$ of cold saline was injected at one end, and circulated in the lumen by alternately lifting and lowering the end several times. The end was snipped off, and the washing expelled into a tube by injecting air at the other end. The recovered fluid, $c .0 .8 \mathrm{ml}$, was spun at $2000 \mathrm{~g}$ at room temperature. The deposit and the supernate were inspected to exclude contamination with blood. The supernate was then titrated as for copro-antibody.

Fractionation of serum proteins. Up to $5 \mathrm{ml}$ of serum were filtered through Sephadex G-200. The effective column height was $84 \mathrm{~cm}$ and the diameter $4 \mathrm{~cm}$, with a flow rate of $36 \mathrm{ml}$ per hr. About 5-ml volumes were collected in tubes in an LKB automatic sample collector coupled to a drop counter. The protein concentration of each sample was determined spectrophotometrically. Samples containing IgM and IgG fractions were pooled separately, and concentrated by dialysis against polyethylene glycol to the original serum volume. Macroglobulins in some sera were inactivated by ethanethiol treatment (Deutsch and Morton, 1957).

\section{RESULTS \\ Active immunisation}

The results of inoculating 1, 10 and $100 \mathrm{MED}$ of $V$. cholerae $12 \mathrm{r}$ into ileal loops of normal and vaccinated rabbits are summarised in table $I$. The confidence intervals of binomial probabilities were read from the tables of Diem (1962). The El Tor vaccine seemed the most effective, as it was the only one to confer significant protection $(P<0.05)$ against $100 \mathrm{MED}$. All the vaccines, including the Inaba strain of classical vibrio, protected well against $10 \mathrm{MED}(\mathrm{P}<0.01)$. But the formolised vaccine was definitely inferior to live or steamed vaccines made from the same strain $(P<0.05)$, the latter two being equally potent. The immunity was undiminished for at least $4 \mathrm{wk}$ after the last vaccination. Indeed, comparison of groups II, III and IV suggests that the immunity probably took over 3 wk from the first dose to develop fully, and then two doses proved as good as four doses. The vibrios multiplied 


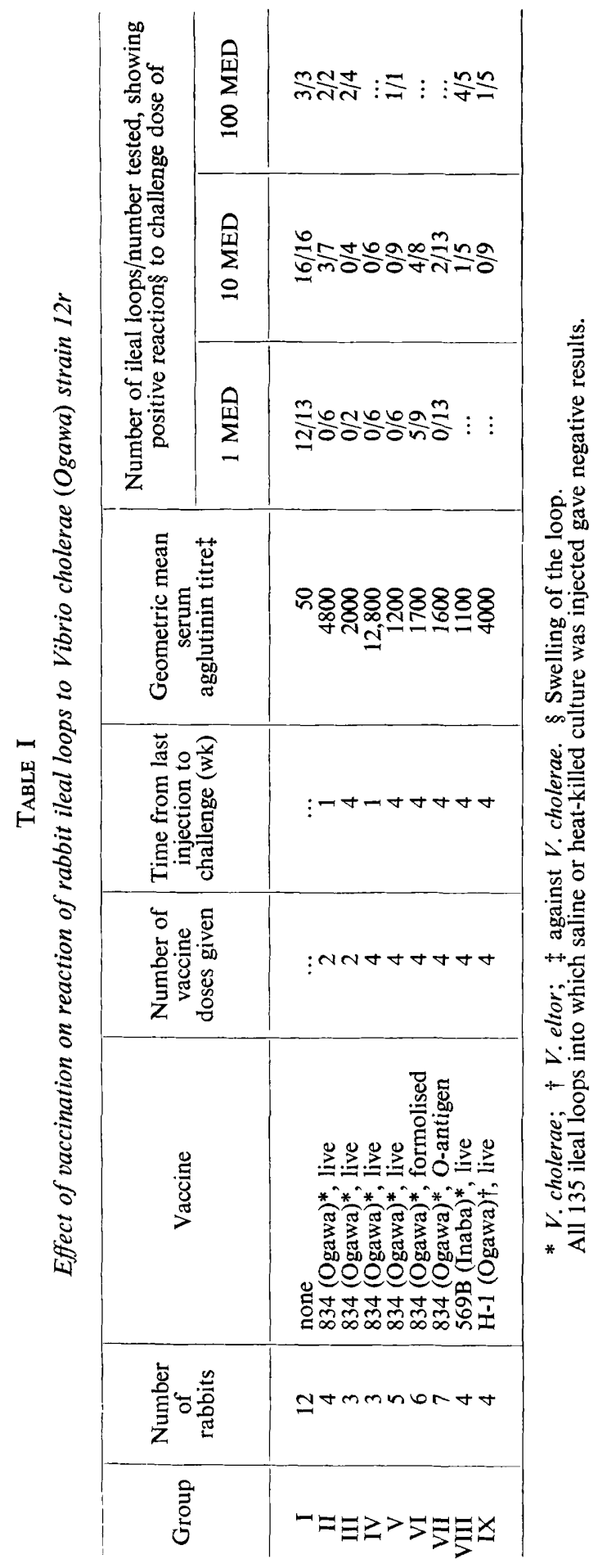


normally in the reactive loops of vaccinated animals, the colony counts in the fluids being comparable to those in unvaccinated rabbits, viz., 106-108 CFU

TABLE II

Multiplication of $V$. cholerae $12 r$ in 18-hr intestinal loops of vaccinated rabbits

\begin{tabular}{|c|c|c|c|c|}
\hline \multirow{2}{*}{ Rabbit no. } & \multirow{2}{*}{ Fluid in loop } & \multicolumn{2}{|c|}{ Number (CFU) of $V$. cholerae } & \multirow{2}{*}{ Increase } \\
\hline & & injected & recovered & \\
\hline $\begin{array}{l}294 \\
295 \\
296 \\
296 \\
296 \\
297 \\
297 \\
301\end{array}$ & $\begin{array}{l}- \\
\bar{t} \\
- \\
- \\
- \\
+\end{array}$ & $\begin{array}{l}4 \times 10^{6} \\
4 \times 10^{6} \\
4 \times 10^{6} \\
4 \times 10^{6} \\
4 \times 10^{5} \\
4 \times 10^{5} \\
4 \times 10^{6} \\
4 \times 10^{6}\end{array}$ & $\begin{array}{r}2 \times 10^{6} \\
3.5 \times 10^{8} \\
57 \times 10^{8} \\
82 \times 10^{7} \\
53 \times 10^{6} \\
19 \times 10^{6} \\
36 \times 10^{7} \\
27 \times 10^{8}\end{array}$ & $\begin{array}{l}\times \frac{1}{2} \\
\times 88 \\
\times 1900 \\
\times 200 \\
\times 190 \\
\times 50 \\
\times 90 \\
\times 700\end{array}$ \\
\hline
\end{tabular}

TABLE III

Effect of vaccination on reaction of guinea-pig ileal loops challenged with $V$. cholerae $12 r$ (figures in brackets are percentages)

\begin{tabular}{|c|c|c|c|c|c|c|c|}
\hline \multirow{2}{*}{\multicolumn{2}{|c|}{ Vaccine }} & \multirow{2}{*}{$\begin{array}{l}\text { Number } \\
\text { of doses } \\
\text { given }\end{array}$} & \multirow{2}{*}{$\begin{array}{l}\text { Time from } \\
\text { last } \\
\text { injection to } \\
\text { challenge } \\
\text { (wk) }\end{array}$} & \multirow{2}{*}{$\begin{array}{l}\text { Geometric } \\
\text { mean } \\
\text { serum } \\
\text { agglutinin } \\
\text { titre }\end{array}$} & \multicolumn{3}{|c|}{$\begin{array}{l}\text { Number of ileal loops/number tested, } \\
\text { showing positive reaction to challenge } \\
\text { dose of }\end{array}$} \\
\hline & & & & & 0 CFU & $15-30 \mathrm{CFU}$ & $180-300 \mathrm{CFU}$ \\
\hline $\begin{array}{l}\text { None } \\
834 \text {, live } \\
834 \text {, live } \\
834 \text {, live } \\
834 \text {, live } \\
834 \text {, formol } \\
834, \text { O-anti } \\
834,56^{\circ} \mathrm{C} \text { f } \\
\text { Water vibri } \\
\text { Escherichia }\end{array}$ & 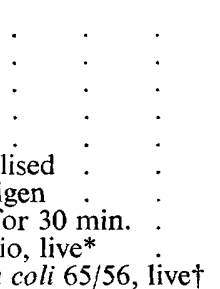 & $\begin{array}{l}3 \\
2 \\
4 \\
4 \\
4 \\
4 \\
4 \\
4 \\
4\end{array}$ & $\begin{array}{l}\cdots \\
1 \\
4 \\
1 \\
4 \\
4 \\
4 \\
4 \\
4 \\
4\end{array}$ & $\begin{array}{r}<50 \\
500 \\
200 \\
350 \\
600 \\
100 \\
100 \\
60 \\
<50 \\
<50\end{array}$ & $\begin{array}{l}21 / 80(26) \\
0 / 8 \\
0 / 2 \\
0 / 19 \\
4 / 61(7) \\
6 / 25(24) \\
1 / 13(8) \\
7 / 22(32) \\
4 / 16(25) \\
15 / 45(33)\end{array}$ & $\begin{array}{l}28 / 36(78) \\
6 / 8(75) \\
2 / 2 \\
8 / 19(42) \S \\
18 / 34(53) \S \\
12 / 19(63) \\
4 / 13(31) \S \\
9 / 17(53) \S \\
6 / 11(55) \ddagger \\
13 / 17(76)\end{array}$ & $\begin{array}{c}22 / 22(100) \\
5 / 8(62) \S \\
2 / 2 \\
6 / 19(31) \S \\
15 / 35(31) \S \\
8 / 11(72) \\
9 / 13(69) \ddagger \\
11 / 17(65) \S \\
8 / 12(66) \S \\
14 / 17(82)\end{array}$ \\
\hline
\end{tabular}

* Nanking NCTC 8042; † enteropathogenic O26,K60,H- (Ghosh, 1969).

$\ddagger \mathrm{P}<0 \cdot 05$, compared with controls; $\S \mathrm{P}<0 \cdot 01$, compared with controls.

per $\mathrm{ml}$. But in protected loops, even in the same animal, the increase was restricted (table II).

The experiments on guinea-pigs (table III) were more difficult to interpret, since the response in normal animals was erratic. Moreover, even the smallest challenge dose employed was probably several times the MED. Nevertheless, the general trend was similar to that in rabbit loops. Of the three additional vaccines tested, the cholera vaccine heated to $56^{\circ} \mathrm{C}$ for $30 \mathrm{~min}$. was highly effective; the live vaccine from the enteropathogenic Escherichia coli was 
ineffective. Curiously, the Nanking water vibrio seemed to confer good protection without stimulating serum antibodies to the challenge strain.

\section{Passive protection tests}

The results of two consecutive series are presented in table IV. In the first series all baby rabbits were protected to some extent $(\mathrm{P}<0.05, \mathrm{~F}$ test $)$,

TABLE IV

Incidence of death or of onset of self-limiting diarrhoea in baby rabbits challenged with c. $5 \mathrm{MED} V$. cholerae 12r, 4-6 hr after intraperitoneal passive immunisation with pooled serum from two actively immunised adult rabbits

\begin{tabular}{|c|c|c|c|c|c|c|}
\hline \multirow[b]{2}{*}{ Series } & \multirow[b]{2}{*}{ Group } & \multirow{2}{*}{$\begin{array}{c}\text { Vaccine strain used to } \\
\text { produce immunising serum }\end{array}$} & \multicolumn{2}{|c|}{ Titre of test antiserum } & \multicolumn{2}{|c|}{$\begin{array}{l}\text { Number of passively immunised } \\
\text { animals/number tested, that when } \\
\text { challenged with } 5 \mathrm{MED} V \text {. cholerae }\end{array}$} \\
\hline & & & agglutinin & vibriocidin & died (after time in hr) & $\begin{array}{l}\text { developed } \\
\text { diarrhoea } \\
\text { (after time } \\
\text { in hr) but } \\
\text { recovered }\end{array}$ \\
\hline 1 & $\begin{array}{l}\text { A } \\
\text { B } \\
\text { C } \\
\text { D }\end{array}$ & $\begin{array}{l}\text { 834, live, } 2 \text { doses } \\
834 \text {, live, } 4 \text { doses } \\
834 \text {, formolised, } 4 \text { doses } \\
834 \text {, O-antigen, } 4 \text { doses }\end{array}$ & $\begin{array}{r}6400 \\
12,800 \\
3200 \\
3200\end{array}$ & $\begin{array}{l}10^{7} \\
10^{8} \\
10^{6} \\
10^{6}\end{array}$ & $\begin{array}{l}4 / 10(48,80,88,90) \\
3 / 9(56,58,82) \\
3 / 10(42,71,88) \\
4 / 10(40,44,54,82)\end{array}$ & $\begin{array}{l}0 \\
0 \\
0 \\
0\end{array}$ \\
\hline 2 & $\begin{array}{l}E \\
F \\
G\end{array}$ & $\begin{array}{l}569 \mathrm{~B} \text {, live, } 4 \text { doses } \\
34^{*} \text {, live, } 4 \text { doses } \\
834^{\dagger} \text {, live, } 2 \text { doses }\end{array}$ & $\begin{array}{r}800 \\
3200 \\
800\end{array}$ & $\begin{array}{l}10^{4} \\
\dddot{104}\end{array}$ & $\begin{array}{l}3 / 7(54,55,104) \\
3 / 8(20,34,82) \\
7 / 10(29,30,32 \times 3 \\
\quad 48,56)\end{array}$ & $\begin{array}{l}2 / 7(32,56) \\
1 / 8(72) \\
0\end{array}$ \\
\hline Control & $A-G$ & None & 50 & $\ldots$ & $\begin{array}{l}22 / 22(\text { mean } 26, \text { SD } \\
\left.4 \frac{1}{2} \mathrm{hr}\right) \ddagger\end{array}$ & 0 \\
\hline
\end{tabular}

* V. eltor Ogawa, rugose, from patient; Philippines, 1962.

† Same serum as group A (table I), heated $30 \mathrm{~min}$. at $65^{\circ} \mathrm{C} ; 1.5 \mathrm{ml}$ to each animal.

$\ddagger$ Fifteen had terminal diarrhoea; mean time of onset $21 \mathrm{hr}$, SD $6 \frac{1}{2} \mathrm{hr}$.

i.e., all lived beyond $34 \mathrm{hr}$, which was the longest survival time for any of the 22 controls. About one-third ultimately succumbed within the observation period. The apparent increase in death-time in the first group (mean $78 \mathrm{hr}$ ) compared with that in the rest of the series (mean $60 \mathrm{hr}$ ) is not statistically significant. The antisera used in the second series appeared generally less effective. The difference was, however, slight. Again the Inaba and El Tor Ogawa vaccines proved quite effective against the classical Ogawa strain. The formolised vaccine did not appear inferior.

Teale (1935) had observed that heating salmonella and shigella antisera for $30 \mathrm{~min}$. at $65^{\circ} \mathrm{C}$ (now known to inactivate macroglobulins) destroyed their protective power without affecting the agglutinin titres. Similar heating of the 
highly protective serum used in group A did cause a marked loss of its efficacy. The serum agglutinin titre, although decreased, still remained comparable to that of the more effective unheated Inaba antiserum.

TABLE V

Agglutinin titre in the serum, and in the washings of ileum and caecum, of baby rabbits passively immunised by intraperitoneal injection of $1 \mathrm{ml}$ of concentrated antiserum from actively immunised adult rabbits

\begin{tabular}{c|c|c|c|c|c}
\hline $\begin{array}{c}\text { Serial no. of } \\
\text { baby rabbit }\end{array}$ & $\begin{array}{c}\text { Nature of serum } \\
\text { injected and } \\
\text { concentration }\end{array}$ & $\begin{array}{c}\text { Time from } \\
\text { injection of } \\
\text { serum to } \\
\text { killing (hr) }\end{array}$ & serum & ileal washings & caecal washings \\
\hline 189 & Normal, $\times 3$ & 6 & $<10$ & $<5$ & $\ldots$ \\
211 & Normal, $\times 3$ & 6 & $<10$ & $<5$ & $\ldots$ \\
124 & Immune, $\times 5$ & 6 & 1600 & 40 & $\ldots$ \\
125 & Immune, $\times 5$ & 6 & 800 & 40 & $\ldots$ \\
188 & Immune, $\times 3$ & 6 & 400 & 40 & $\ldots$ \\
190 & Immune, $\times 3$ & 6 & 1600 & $<5$ \\
104 & Immune, $\times 1 \cdot 5$ & 18 & 800 & $<5$ \\
105 & Immune, $\times 5$ & 18 & 3200 & 5 & $\ldots$ \\
114 & Immune, $\times 4$ & 18 & 800 & 20 & 5 \\
115 & Immune, $\times 4$ & 18 & 1600 & 5 & \\
\hline
\end{tabular}

TABLE VI

Agglutinin titres of rabbit antisera, and of their IgM and IgG fractions before and after treatment with ethanethiol

\begin{tabular}{|c|c|c|c|c|c|c|c|c|}
\hline \multirow{3}{*}{$\begin{array}{l}\text { Serial } \\
\text { no. of } \\
\text { rabbit }\end{array}$} & \multirow{3}{*}{$\begin{array}{l}\text { Number of } \\
\text { doses of } \\
\text { vaccine }\end{array}$} & \multirow{3}{*}{$\begin{array}{c}\text { Day of } \\
\text { bleeding* }\end{array}$} & \multicolumn{6}{|c|}{ Agglutinin titre against $V$. cholerae of } \\
\hline & & & \multicolumn{2}{|c|}{ serum } & \multicolumn{2}{|c|}{$\begin{array}{l}\text { IgG fraction } \\
\text { of serum }\end{array}$} & \multicolumn{2}{|c|}{$\begin{array}{l}\text { IgM fraction } \\
\text { of serum }\end{array}$} \\
\hline & & & Control & Treated $\dagger$ & Control & Treated $\dagger$ & Control & Treated $\dagger$ \\
\hline $\begin{array}{l}106 \\
107\end{array}$ & $\begin{array}{l}4 \\
4\end{array}$ & $\begin{array}{l}28 \\
28\end{array}$ & $\begin{array}{l}1600 \\
3200\end{array}$ & $\begin{array}{l}3200 \\
3200\end{array}$ & $\begin{array}{l}\ldots \\
\ldots\end{array}$ & $\ldots$ & $\begin{array}{l}\ldots \\
\ldots\end{array}$ & $\ldots$ \\
\hline $\begin{array}{l}108 \\
109\end{array}$ & $\frac{2}{2}$ & $\begin{array}{l}15 \\
15\end{array}$ & $\begin{array}{r}400 \\
3200\end{array}$ & $\begin{array}{l}400 \\
400\end{array}$ & $\begin{array}{r}60 \\
100\end{array}$ & $\begin{array}{r}40 \\
100\end{array}$ & $\begin{array}{r}20 \\
120\end{array}$ & $\begin{array}{l}<20 \\
<20\end{array}$ \\
\hline
\end{tabular}

Ileal washings collected $6 \mathrm{hr}$ after antiserum administration contained some agglutinin (table V). The titres in undiluted ileal contents must have been much higher. The titres were not related to the serum titres and fell considerably by the next day though the serum titres remained constant. It is unlikely that such gross differences were artefacts from variables in washing procedure. 
Ethanethiol treatment (table VI) and column chromatography (fig. 2) showed that most of the specific agglutinin was in the IgG fraction even after

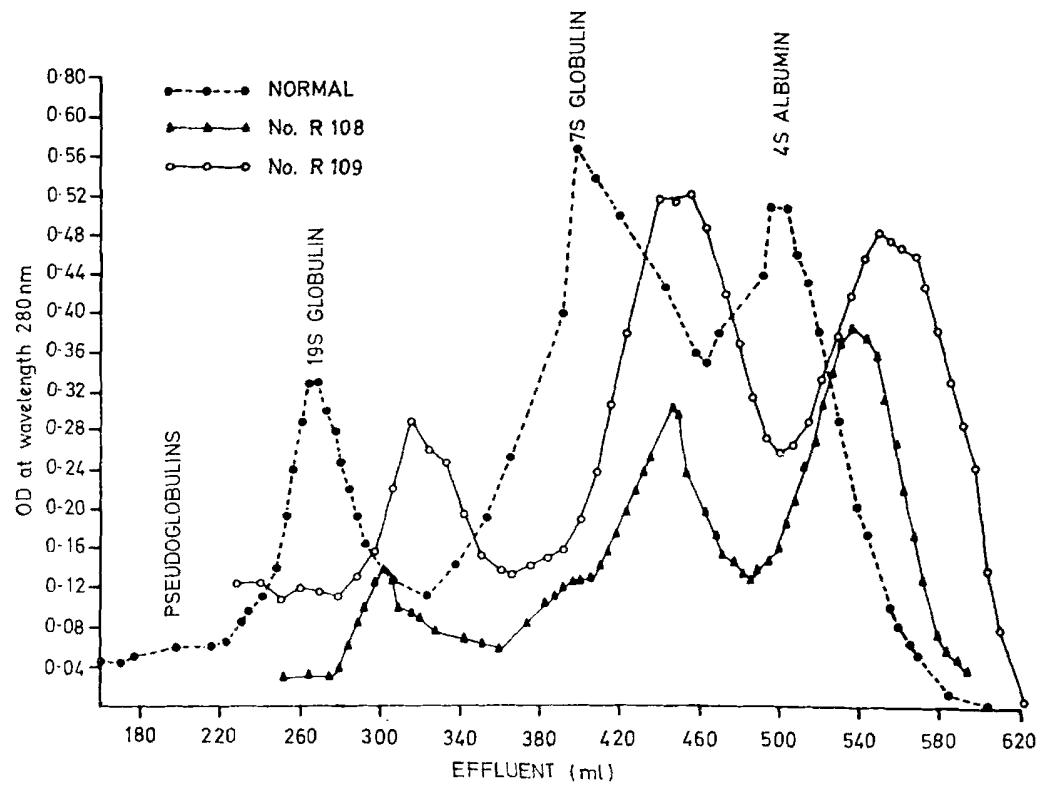

FIG. 2.-Chromatographic fractionation of one normal and two immune sera by filtration through Sephadex $\mathrm{G}-200$ column with $0 \cdot 2 \mathrm{M}$ Tris buffer at $p \mathrm{H} 8$. As the ratios of IgG and IgM fractions determined by measuring the areas with a planimeter were similar in all cases, serological tests with each fraction were needed for estimating antibody activities (see table VI).

TABLE VII

Agglutinin titres of extracts of the caecal contents of vaccinated adult rabbits

\begin{tabular}{c|c|c|c}
\hline $\begin{array}{c}\text { Serial no. } \\
\text { of rabbit }\end{array}$ & $\begin{array}{c}\text { Number of doses } \\
\text { of vaccine given }\end{array}$ & $\begin{array}{c}\text { Time after last } \\
\text { dose of vaccine (wk) }\end{array}$ & $\begin{array}{c}\text { Agglutinin titre of caecal } \\
\text { contents against } V . \text { cholerae }\end{array}$ \\
\hline N-1 & 0 & $\ldots$ & 5 \\
N-2 & 0 & $\cdots$ & 10 \\
\hline 13 & 1 & 1 & 20 \\
14 & 1 & 1 & 20 \\
18 & 1 & 1 & 80 \\
96 & 2 & 1 & 80 \\
277 & 4 & 1 & 10 \\
\hline 97 & 2 & 4 & $<10$ \\
98 & 2 & 4 & 10 \\
264 & 4 & 4 & 10 \\
265 & 2 & 4 & $<5$ \\
276 & 2 & & \\
\hline
\end{tabular}

two doses of vaccine, although occasionally a substantial proportion was contained also in IgM, as in rabbit no. 109. 
The vibriocidal titres were proportional to the agglutinin titres. Neither was related to the degree of protection to the challenge doses in loops or in baby rabbits.

\section{Discussion}

The data presented here confirm earlier observations on the effectiveness of live parenteral vaccines injected immediately before enteric challenge. They reveal further that the resistance holds well for at least $4 \mathrm{wk}$ after the vaccination, which would exclude any essential role of copro-antibody as usually understood. Most workers have in fact failed to detect antibody in rabbit gut by conventional methods, though our data did indicate the transient presence of traces of copro-antibody (table VII). Recently the lining cells of alimentary tract have been shown to excrete peculiar IIS IgA globulins that are not readily detected by traditional serological methods (Rosen et al., 1968). Their duration and role in gut infection remain undefined.

The satisfactory protective power of heat-killed vaccine in active and passive protection tests agrees with the observations of Jenkin and Rowley (1960) and of Freter (1964). The failure of Panse et al. (1964) to protect baby rabbits may have resulted from the use of litters as units allowing a systematic error, or from a peculiarity of the vaccine strain. The well-known importance of the vaccine strain is emphasised by the better protection in loop experiments from an El Tor vaccine than from vaccines made from the challenge strain, though another El Tor strain nearly equalled the homologous strain in baby rabbits. It is interesting that in a field trial in the Philippines an El Tor vaccine appeared better than a classical cholera vaccine against cholera caused by the El Tor biotype (Standfast, 1969).

The scanty published data indicate that the resistance is not antitoxic. Neither Finkelstein (1962) nor Panse et al. could save baby rabbits challenged with vibrio cultures or crude enterotoxin by administering antitoxic serum. Conversely we were unable to delay the death of two baby rabbits given the potent antiserum used in group A, table IV, when these were challenged with crude enterotoxin from the homologous strain. The protective actions of the steamed $\mathrm{O}$-antigen vaccine, and possibly of the avirulent water vibrio, also support the probability of an antibacterial immunity. Our data do not show whether the failure of vibrios to thrive in protected animals resulted from actual destruction (Jenkin and Rowley) or from retardation of growth (Freter; Bhattacharya and Mukerjee, 1968). There was, however, no sign of the phagocytosis described by Jenkin and Rowley.

The lack of correlation between antibody titre and protective power of antisera agrees with the observations of Feeley (1965) in baby rabbits. The importance of $\mathrm{O}$-antigens is rendered more doubtful by the observation of the apparent protection given by vaccine made from a water vibrio, in keeping with the similar success of Burrows (1953) in orally challenged guinea-pigs. Timakov and Skavronskaya (1961) found that the protective powers of various enterobacterial vaccines in mouse-protection tests were related to their protein antigens, which provoked the production of low-titre precipitins. Moreover, 
partially purified lipopolysaccharide antigens have proved sometimes less effective than whole-cell cholera vaccines in controlled field trials (Standfast).

Feeley recorded that sera collected later during prolonged vaccination became progressively more protective, contained increasing proportion of IgG globulins, and gave additional precipitin bands in gel diffusion plates. Our data suggest the possibility that the increased protection after 4 wk of vaccination was a function of time following an adequate stimulus rather than of the number of doses. In any case two doses followed by a long interval was adequate. Vaccines have been given to rabbits in all the experiments in doses, judged by body weight and agglutinin response, much higher than would be tolerated by man (Oseasohn, Benenson and Fahimuddin, 1965). In some field trials one dose of vaccine proved as effective as two, and protection after $3 \mathrm{mth}$ was better than that obtained earlier (Standfast). The passive protection tests with heated antiserum indicated further that the greater part of protective action probably did not involve heat-stable IgG globulins, which is compatible with the recent data on the peculiar nature of $\operatorname{IgA}$ intestinal antibody already mentioned.

Whatever may be the protective antigen and its optimal dose schedule, there can be little doubt that selection of the vaccine strain and its processing will largely influence the protectiveness of the vaccine. A suitable experimental model for bioassay is thus all the more important. Meanwhile the customary belief that a precise animal model closely simulating the natural disease will necessarily be the most relevant system for immunological studies has been shaken by recent attempts to correlate results of field trials of pertussis and typhoid vaccines with assays in animal models (Standfast). The relevance for this purpose of the various models of experimental cholera must thus remain speculative until multicentric controlled field trials define with certainty the relative merits of at least three vaccines that could then be tried in animals. Unfortunately the various field trials on cholera have so far been made with different groups of vaccines, so that it is extremely difficult to estimate the relative efficiency of any three vaccines over a number of trials.

\section{SUMMARY}

Parenterally vaccinated rabbits and guinea-pigs, and passively immunised baby rabbits, were challenged intra-intestinally with graded doses of a cholera vibrio strain. All vibrio vaccines, possibly including one made from an avirulent water vibrio, appeared fairly protective. Live and heat-killed vaccines seemed equally effective, and were superior to a formolised vaccine. The immunity seemed antibacterial, but possibly independent of the agglutinating antibodies. Suitability of a vibrio strain for vaccine production was not reflected in its specific serotype. Development of maximum resistance seemed to take several weeks after adequate dosage, and repetition of doses during this period showed no immediate advantage. The duration of immunity was, however, not ascertained. 
I am indebted to Mr W. Lutz of the Social Science Department for advice on statistical matters, and to Dr D. M. Weir of this department for guidance in immunological techniques.

\section{REFERENCES}

Bhattacharya, P., ANd MukerJee, S. . 1968. J. Hyg., Camb., 66, 307.

Burrows, W. . . . . . . 1953. J. Infect. Dis., 92, 152.

BurRows, W., AND WARE, L. $\quad . \quad$. 1953. Ibid., 92, 164.

Choukevitch, J. $\quad$. . . . . 1911. Annls Inst. Pasteur, Paris, 25, 433.

De, S. N., Lahiri, P. K. C., Ghosh, 1958. Ind. J. Med. Res., 46, 355.

M. L., AND MONDAL, A.

Deutsch, H. F., AND Morton, J. I. . 1957. Science, N.Y., 125, 600.

DIEM, K. (ED.) . . . . . 1962. Documenta Geigy Scientific

Feeley, J. C. . . . . . 1965. In Proc. Cholera Res. Symp., Washing-

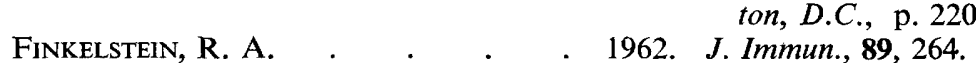

FRETER, R. $\quad . \quad$. $\quad . \quad \quad . \quad \quad$. 1962. J. Infect Dis., 111, 37.

, $\quad$ • . . . . . . 1964. Bull. Wld Hlth Org., 31, 825.

GHOSH, H. K. $\quad$ - $\quad$. $\quad$ - $\quad$ - $\quad$ - 1969. Far East Med. J., 5, 53.

Jenkin, C. R., ANd Rowley, D. . . 1960. Br.J. Exp. Path., 40, 474.

Metchnikoff, E. . . . . 1894. Annls Inst. Pasteur, Paris, 8, 529.

Oseasohn, R. O., Benenson, A. S., AND 1965. Lancet, 1, 450.

FAHIMUdDIN, M.

Panse, M. V., Jhala, H. I., AND Dutta, 1964. J. Infect. Dis., 114, 26.

N. K.

Rosen, R. D., Councilman, M., Conrad, 1968. J. Immun., 100, 707.

C. H., Butler, W. T., AND Rose, H. M.

SANARELLI, G.

1921. Annls Inst. Pasteur, Paris, 35, 761.

Standfast, A. F. B. $\quad$ - $\quad$. $\quad$ - $\quad$. 1969. Br. Med. Bull., 25, 189.

Teale, F. H. . . . . . . 1935. J. Immun., 28, 241.

Timakov, V. D., and Skavronskaya, 1961. J. Microbiol. Epidem., Immunobiol., 32, A. G. 393. 